\title{
A survey of dietary intake in the Medan City community during the COVID-19 pandemic
}

\author{
Posman Sibuea $^{1 *}$, and Oktrina Yohana Nainggolan ${ }^{1}$ \\ ${ }^{1}$ Departement of Agricultural Product of Technology, Faculty of Agriculture, Unika Santo Thomas, \\ Setia Budi Street, Medan, 20135, North Sumatera, Indonesia
}

\begin{abstract}
Food is an essential requirement for people to live a healthy, active, and productive existence sustainably. Increasing the nutritional content consumed during the COVID-19 pandemic is one of the critical needs for improving the immune system or body's response. This research aims to obtain information on people's food consumption patterns during the COVID-19 pandemic in five sub-districts of Medan City. The study's findings indicate that individuals depend on nutritious and functional meals, including fruits and vegetables, to enhance body immunity during this pandemic. Moreover, the study observed that 74.4 percent of people consumed food derived from the fruit and vegetable groups as a source of vitamins and minerals. The percentage of food intake from the functional food group was 71.2 percent. Eighty-eight percent of respondents consumed herbal infusions from the spice category as a functional drink as a source of antioxidants. The intake level of diversified foods reaches 68 percent, and the pattern of consumption of varied foods with balanced and safe nutrition has been primarily satisfied.
\end{abstract}

\section{Introduction}

The World Health Organization (WHO,) since March 2020, has declared the coronavirus disease as a pandemic disease that has affected large numbers of people and occurs in many places. The spread of coronavirus disease (COVID-19) has rapidly impacted people's lives in consuming food to maintain body resistance or immunity [1]. The impact of the Covid19 pandemic is presumed as the reason behind people's consumption patterns to change. People prefer to cook and eat at home because there are government regulations to stay at home and practice social distancing. Staying at home during this pandemic has emerged ecommerce which has become a mainstay and has compelled food consumption patterns to change from retail and outlets offline to online. The primary factor driving food shopping decisions online is the convenience of reducing direct contact with other people.

\footnotetext{
*Corresponding author: sibueaposman@gmail.com
} 
Food and nutrition play an essential role in human life. Assessment of food consumption is the earliest measurement method used to assess stages of nutritional deficiency. Nutritional deficiency starts from a lack of intake of nutrients in food that can reduce the body's resistance [2]. The role and function of nutrition have been known to strengthen the body's immunity. Thus lacking certain nutrients can cause an impaired immune system and be physically weakened, which causes some obstructions in their activities. Macronutrients such as protein, fatty acids linoleic, palmitic, micronutrients such as vitamin $\mathrm{C}$, vitamin $\mathrm{E}$, vitamin $\mathrm{A}$, vitamin $\mathrm{B} 6, \mathrm{~B} 12$, minerals $\mathrm{Zn}, \mathrm{Cu}$, and $\mathrm{Fe}$ are necessary for the immune system to function correctly. It is now widely acknowledged that the dual role of food performs a major impact in determining the quality of public health, which not only does the food fulfil the stomach and give a delightful flavor on the tongue, but also has functional advantages for the body due to the presence from several bioactive substances [3].

Besides its function as a conventional nutrient provider, the dietary intake daily should also be based on functional features. Functional food has three basic functions, namely 1 . High nutritional value; 2. Attractive appearance (good color and taste) and 3. Provides beneficial physiological effects for the body. Functional foods are classified as Foods for Specific Health Uses (FOSHU). FOSHU must contain bioactive compounds, antioxidants, and dietary fiber $[2,4]$. The most efficient strategy to prevent COVID-19 is to establish a habit of eating healthy and nutritious foods for those who have not been vaccinated.

According to preliminary survey data, individuals are predominantly consuming green tea throughout the pandemic. Drinking tea in the morning before commencing activities is something that is done on a regular basis and is usually served on the table. Tea consumption has become a new habit for boosting the body's antioxidant status $[5,6]$. The antioxidant catechins in green tea can reduce the incidence of influenza in humans. Although the mechanism of the bioactive compounds in green tea as anti-viral is not yet known, it is suspected that catechins which are known as strong antioxidants, can prevent free radical chain reactions that inhibit influenza A virus infection and induce viral agglutination in cells and strengthen immunity [7]. The objective of this paper is to characterize the consumption habits of the inhabitants of Medan when it comes to deciding food as a nutritional intake to boost body immunity during the COVID-19 pandemic. The data collected might provide a decent starting point for scientific suggestions on consuming a variety of nutritious, balanced, and safe diets.

\section{Research Method}

\subsection{Data Collection Research}

This research is a descriptive survey to describe people's eating patterns in five subdistricts, Medan city. The data collected in this study are primary data and secondary data. Primary data was obtained through a questionnaire using a list of questions that had been prepared in advance. Sampling was carried out as stratified random sampling with the arrangement of strata before sampling $[8,9]$.

\subsection{Data Analysis}

Data analysis was carried out descriptively to describe people's food consumption patterns. The pattern of food consumption is obtained through questions about the type and amount of food consumed per day. While the secondary data used is data obtained from the questions regarding the categories and number of food intake. Meanwhile, the secondary data was obtained from the agencies related to this research, such as the Central Statistics 
Agency and the Food Security Agency, as well as from various literature, journals, and the internet that support this research.

\section{Results and Discussion}

\subsection{Respondent's identity and information on COVID-19}

Respondents involved in this study amounted to 125 people. Table 1 shows that of the 125 respondents, most respondents' occupations are entrepreneurs at $30.4 \%$, followed by those who do not work/housewives as much as $27.2 \%$ and in the third-place are civil servants, civil servant, military as much as $20.8 \%$. Meanwhile, respondents who work as private employees are in fourth place, which is $16 \%$ followed by respondents whose livelihood is in transportation (public transportation, rickshaw, and Gojek drivers) which is $5.6 \%$ in fifth place.

Table 1. Types of occupation of respondents

\begin{tabular}{|c|c|c|}
\hline Occupation & Number of Households & Percentage (\%) \\
\hline Civil Servant / Military & 26 & 20.8 \\
\hline Private Employee & 20 & 16.0 \\
\hline Entrepreneur & 38 & 30.4 \\
\hline Public Transportation Driver & 7 & 5.6 \\
\hline Unemployed / Housewife & 34 & 27.2 \\
\hline Total & 125 & 100 \\
\hline
\end{tabular}

The age group of respondents is shown in Table 2. Most respondents are aged 35-40 years, which is $52.8 \%$ of respondents, followed by respondents aged $46-50$ years as much as $19.2 \%$, and following in the third place the respondent's age group is $41-45$ years as much as $14.4 \%$, then in the fourth rank the respondent age group is $51-55$ years as much as $8.8 \%$ and finally in the fifth place is the 56-60 years age group as much as $4.8 \%$.

Table 2. Age group of respondents

\begin{tabular}{|c|c|c|}
\hline Age & Number of Households & Percentage (\%) \\
\hline $35-40$ & 66 & 52.8 \\
\hline $41-45$ & 18 & 14.4 \\
\hline $46-50$ & 24 & 19.2 \\
\hline $51-55$ & 11 & 8.8 \\
\hline $56-60$ & 6 & 4.8 \\
\hline Total & 125 & 100 \\
\hline
\end{tabular}

Regarding the sources of information about COVID-19 obtained by respondents, it can be seen in Table 3. Respondents received the most information from the internet or social media, 69 people or $69.60 \%$ followed by television and radio media with the second-order as many as 28 people or $22.4 \%$. Respondents who received information from chat applications such as line, WhatsApp, SMS, and others were in third place as many as eight people $6.4 \%$. Meanwhile, newspapers, magazines and other people are directly in the $4^{\text {th }}$ and fifth place with one person or $0.8 \%$. The source of information in the high order is obtained from television and the internet because almost every day, the National COVID19 task force, through a spokesperson, conveys the latest developments about COVID-19 in Indonesia and each region. 
Table 3. Sources of information about COVID-19 obtained by respondents

\begin{tabular}{|c|c|c|}
\hline $\begin{array}{c}\text { COVID-19 information } \\
\text { acquired }\end{array}$ & Number of People & Percentage (\%) \\
\hline Television/Radio & 28 & 22.4 \\
\hline Internet/Social Media & 69 & 69.6 \\
\hline Messaging Application & 8 & 6.4 \\
\hline Newspaper/Magazine & 1 & 0.8 \\
\hline Other & 1 & 0.8 \\
\hline Total & 125 & 100 \\
\hline
\end{tabular}

\subsection{Food Diversity}

During the COVID-19 pandemic, most respondents had breakfast in the morning, as shown in Table 4. The majority of respondents usually had breakfast, 93 households or $74.4 \%$, while respondents who sometimes had breakfast were 26 households or $20.8 \%$. Respondents who did not eat breakfast were six households or $4.8 \%$. This information about breakfast habits shows that the breakfast program still needs to be socialized better in the future and become part of the community nutrition improvement program during the Covid-19 pandemic.

Table 4. Breakfast habits of respondents

\begin{tabular}{|c|c|c|}
\hline Types of Behaviour & Number of Households & Percentage (\%) \\
\hline Always & 93 & 74.4 \\
\hline Sometimes & 26 & 20.8 \\
\hline Nothing & 6 & 4.8 \\
\hline Total & 125 & 100 \\
\hline
\end{tabular}

The COVID-19 pandemic has brought valuable experience to respondents to improve the quality of diversity in food consumption, as shown in Table 5 and Table 6 . A total of 85 respondents, or $68 \%$, made improvements to food consumption, and as many as 40 respondents, or $32 \%$, did not experience improvement in food consumption diversity. The increase in the variety of food consumption can occur because they want to have a better nutritional intake to support and increase immunity or immunity during the COVID-19 pandemic. Most respondents already understood that excellent nutrition through food was an ideal natural vaccine before getting a medical vaccine. The same thing was also expressed by Calder and Kew [10] to increase immunity is to increase the consumption of functional foods. The more variety of food consumed is expected to increase nutritional intake and improve the immune system.

Table 5. Variation of dietary intake

\begin{tabular}{|c|c|c|}
\hline Variation of Food Intake & Number of Households & Percentage (\%) \\
\hline Yes & 85 & 68 \\
\hline No & 40 & 32 \\
\hline Total & 125 & 100 \\
\hline
\end{tabular}

During the COVID-19 pandemic, maintaining nutritious food intake is essential to increase body resistance so that it is not easy to contract diseases during a pandemic [5]. 
Consumption of functional foods can be an alternative to increase endurance. Table 6 shows that $71.2 \%$ of respondents consumed functional food during the pandemic, and $38.8 \%$ did not consume functional food during the pandemic. In its function as an immunity booster, functional foods are categorized as Foods for Specific Health Uses (FOSHU) because they contain functional ingredients such as bioactive compounds, antioxidants, and dietary fiber [8]. In addition, nutritionists recommend functional foods to recover oxidative stress during a disaster [11].

Table 6. Consumption of functional foods

\begin{tabular}{|c|c|c|}
\hline Functional Food Intake & Number of Households & Percentage (\%) \\
\hline Yes & 89 & 71.2 \\
\hline No & 36 & 38.8 \\
\hline Total & 125 & 100 \\
\hline
\end{tabular}

To improve the immune system, respondents made drinks from various types of spices, as shown in Table 7 and Table 8 . A total of 101 respondents, or $80.6 \%$ of households, made drink ingredients from spices during the COVID-19 pandemic, believed to be able to improve the immune system, while 24 respondents or $19.2 \%$ of households do not consume spices. The high interest in making spiced drinks indicates that respondents want to live a healthy life through increasing consumption of natural products that can be obtained in easily accessible neighborhoods.

Table 7. Respondent habits of making spiced drinks

\begin{tabular}{|c|c|c|}
\hline Spiced Drinks Intake & Number of Households & Percentage (\%) \\
\hline Yes & 101 & 80.8 \\
\hline No & 24 & 19.2 \\
\hline Total & 125 & 100 \\
\hline
\end{tabular}

From 101 respondents or $80.8 \%$ as shown in Table 6 , respondents who use ginger in their daily drinks are $27.2 \%$, bank $23.2 \%$, use lemon, ginger, and cinnamon as much as $21,6 \%$, then lemongrass, galangal, turmeric, and tea drinks as shown in Table 8. Indonesia has a strong tradition of functional foods. People know herbal medicine from local spices that are brewed and drunk in an effort to increase endurance. That said, this ingredient is one of the factors that made the number of new COVID-19 cases in India declined sharply from September 2020 to February 2021 [12].

Table 8. Types of spices used by respondents

\begin{tabular}{|c|c|c|}
\hline $\begin{array}{c}\text { Types of Spices } \\
\text { Used/Spiced Drinks }\end{array}$ & Number of Households & Percentage (\%) \\
\hline Ginger & 34 & 27.2 \\
\hline Bandrek & 29 & 23.2 \\
\hline Lemon, Ginger, Cinnamon & 27 & 21.6 \\
\hline Lemongrass & 2 & 1.6 \\
\hline Galangal & 1 & 0.8 \\
\hline Curcuma & 1 & 0.8 \\
\hline Turmeric, Ginger, Galangal & 11 & 8.8 \\
\hline Mixed of All Spices & 13 & 10.4 \\
\hline Tea & 7 & 5.6 \\
\hline Total & 125 & 100 \\
\hline
\end{tabular}


The COVID-19 pandemic has brought new awareness to the public to eat healthy food to increase body immunity, as shown in Table 9. Eating a balanced diet has become a new habit for 119 respondents or $95.2 \%$. Only a small number of respondents did not consume balanced nutritious food, namely six respondents or $4.8 \%$.

Table 9. Consumption of balanced nutritious food

\begin{tabular}{|c|c|c|}
\hline $\begin{array}{c}\text { Balanced Nutritious Food } \\
\text { Intake }\end{array}$ & Number of households & Percentage (\%) \\
\hline Yes & 119 & 95.2 \\
\hline No & 6 & 4.8 \\
\hline Total & 125 & 100 \\
\hline
\end{tabular}

During the COVID-19 pandemic, respondents increased their consumption of fresh, good-quality fruits and vegetables, as shown in Table 10. Respondents consumed processed fruit and vegetable products directly to obtain the benefits of their nutritional and vitamin content to the public inside the body. Table 9 shows that as many as 93 respondents or $74.4 \%$ and who do not consume vegetables and fruit as many as 32 respondents or $25.6 \%$.

Table 10. Consumption of fruits and vegetables

\begin{tabular}{|c|c|c|}
\hline $\begin{array}{c}\text { Fruits and vegetable } \\
\text { Intake }\end{array}$ & Number of households & Percentage (\%) \\
\hline Yes & 93 & 74.4 \\
\hline No & 32 & 25.6 \\
\hline Total & 125 & 100 \\
\hline
\end{tabular}

Fruits and vegetables were consumed by a greater proportion of respondents than those who did not. This demonstrates that fruits and vegetables are necessary meal items that should not be overlooked on a daily basis. The nutritional content is very significant in increasing the body's resistance from children to adults, although if you must consume a variety of foods which are obtained from various vegetables with different tastes and colors [10]. People have long realized that fruits and vegetables are an excellent source of minerals and vitamins which might be taken to improve overall physical health. Although the nutritional composition of varying sorts of vegetables and fruit varies, these foods provide an alternative for maintaining a healthy diet during the COVID-19 pandemic.

\section{Conclusion}

- The trend of community food consumption in Medan City during the COVID-19 pandemic reveals that eating patterns have changed between before and after the pandemic. People are increasingly encouraged to consume a proper diet, spiceinfused beverages, as well as fruits, vegetables, and functional meals

- During the COVID-19 pandemic, the diet has an impact on the immune system. People feel that consuming nutritious meals strengthens their immune system

- Consumption of herbal infusions derived from the spice group as a functional drink as a source of antioxidants is believed to enhance the body's immunity and prevent COVID-19 infection.

- During the COVID-19 pandemic, there has been a surge in the diversity of food intake in the population, as well as a better knowledge of the benefits of eating a variety of balanced and safe meals. 


\section{References}

1. P. Sibuea. https://analisis.kontan.co.id/news/pangan-fungsional-di-tengah-pandemi. [access at 19 Oktober 2020]

2. F. Clydesdale, Food Tech J, 58, 35-40 (2004)

3. P. Sibuea. Fungsi makanan untuk kesehatan, perspektif baru antioksidan alami untuk gaya hidup sehat. (Bina Media Perintis. Medan, 2013)

4. J. L. Slavin, B. Lloyd, Adv in Nutrition an Int Review J, 3, 506-516 (2012)

5. M. Janssen, B. P. I. Chang, H. Hristov, I. Pravst, A. Proveta, J. Miliard, Frontiers in Nutrition, 8, 1-20 (2021)

6. S. Onishi, T. Mori, H. Kanbar, T. Habe, N. Ota, Y. Kurebayashi, T. Suzuki, J of Funct Foods, 68, 1 (2020)

7. S, M, N, S. Rauf, Survei Konsumsi Pangan (EGC, Jakarta, 2015)

8. S, Metode Penelitian Praktis Untuk Ilmu Sosial dan Ekonomi (BPFE UGM, Yogyakarta, 2016)

9. P. C. Calder, S. Kew, British J of Nutrition, 88, 165-176 (2002)

10. A. T. Vieira, M. M. Teixeira, F. S. Martins, Frontiers in Imm Review Article, 4, 112 (2013)

11. P. Sibuea. https://www.kompas.id/baca/opini/2021/05/30/kebangkitan-makanantradisional. [access at 20 Mei 2020] 